\title{
FATHOM
}

\section{Boats and Knitting Machines: Objects of Doom in Hardy and Conrad}

Navires et autres machines : objets de malheur chez Hardy et Conrad

\section{Stéphanie Bernard}

\section{(2) OpenEdition \\ 1 Journals}

\section{Electronic version}

URL: http://journals.openedition.org/fathom/1300

DOI: $10.4000 /$ fathom. 1300

ISSN: 2270-6798

\section{Publisher}

Association française sur les études sur Thomas Hardy

\section{Electronic reference}

Stéphanie Bernard, «Boats and Knitting Machines: Objects of Doom in Hardy and Conrad », FATHOM [Online], 6 | 2019, Online since 01 October 2019, connection on 16 October 2019. URL : http:// journals.openedition.org/fathom/1300; DOI : 10.4000/fathom.1300 


\title{
Boats and Knitting Machines: Objects of Doom in Hardy and Conrad
}

Navires et autres machines : objets de malheur chez Hardy et Conrad

\author{
Stéphanie Bernard
}

1 Thomas Hardy and Joseph Conrad gave voice and shape to the mood of the times they lived in. Hardy was inspired by long walks through the countryside as much as by journeys by train; evocations of such inventions as the threshing machine in Tess of the d'Urbervilles or the Titanic go along with depictions of old churches and ancient places in his writings. In Conrad, boats - from sail to steam ${ }^{1}-$ are overwhelmingly and obviously present. Gradually with the industrial revolution and the development of technology, objects and machines became - and still are - emblematic of progress, but in an ambivalent way that also signalled danger and the risk of dehumanizing men. We will see how boats, machines and other objects - those "material thing[s] that can be seen and touched" - appear in Hardy's and Conrad's works at the turn of the $20^{\text {th }}$ century and what their representation reveals about the authors' visions of the world and of life itself.

\section{Of boats and men}

2 The first two words in Heart of Darkness, Conrad's most famous work, are those that compose the name of the ship on which the narrator, Marlow, will tell his tale: "The Nellie, a cruising yawl, swung to her anchor without a flutter of the sails, and was at rest" (Conrad 1996, 135). Later on, long delay is caused by the necessity to fix different parts of Marlow's sunken steamer on the Congo River (162). In both cases, the massive and motionless object floating on a river allows for the story and narration to unfold and linger on. 
3 Ships in Conrad often move the story and trigger the narrative because they appear either too motionless, as in Heart of Darkness or as in The Shadow-Line, in which total quietness and absence of wind, together with fever, threaten the whole crew, or uncontrollably restless as in The Nigger of the "Narcissus":

A big, foaming sea came out of the mist; it made for the ship, roaring wildly, and in its rush it looked as mischievous and discomposing as a madman with an axe. [...] $[T]$ he coming wave [...] towered close-to and high, like a wall of green glass topped with snow. The ship rose to it as though she had soared on wings, and for a moment rested poised upon the foaming crest as if she had been a great sea-bird. Before we could draw breath a heavy gust struck her, another roller took her unfairly under the weather bow, she gave a toppling lurch, and filled her decks. (Conrad 1990, 57)

In Lord Jim, the hesitation between these two extremes is contained in the "awful stillness preceding a catastrophe" that characterizes the moments before Jim's fatal jump (Conrad 1989, 108), the water appearing "still - still as a pond, deadly still, more still than ever sea was before" (110-111). But the impending catastrophe never happens, which turns the Patna - the ship from which Jim leaps - into the place and cause of disaster for the protagonist.

5 Jim is fully mistaken as an observer. Although he asserts: "I saw as clearly as I see you now [...]", (Conrad 1989, 107), he misreads the situation he has to face and is an unreliable focaliser. He tries to observe and listen to the pilgrims on board, the crew and the ship herself, but his efforts result in a chaotic vision: "He saw here and there a head lifted off a mat, a vague form uprise in sitting posture, listen sleepily for a moment, sink down again into the billowy confusion of boxes, steam-winches, ventilators" (106).

6 He will eventually stop looking ("I made up my mind to keep my eyes shut", Conrad 1989, 121); but he fails to understand that what he should see has been replaced by an inner vision dictated by his own thoughts and influenced by his romantic mind. ${ }^{3} \mathrm{He}$ does not perceive the concreteness of the people and things in front of him - thirsty and endangered pilgrims, the looming catastrophe as well as the possibility to avert it because he is only open to his own reading and (mis-)understanding of the events taking place around him:

Nothing in the world moved before his eyes, and he could depict to himself without hindrance the sudden swing upwards of the dark sky-line, the sudden tilt up of the vast plain of the sea, the swift still rise, the brutal fling, the grasp of the abyss, the struggle without hope, the starlight closing over his head for ever like the vault of a tomb - the revolt of his young life - the black end. (Conrad 1989, 114) None of this ever happens on the Patna.

This vision, moreover, is conveyed to us through Marlow's narration, as he reports what he remembers of his past conversation with Jim at the time of his trial. These layers of storytelling reinforce the distortion effect because of the distance between the facts and their interpretation, putting into question the possibility of ever reaching the truth. ${ }^{4}$

9 Jim's way of telling about what took place on the Patna, as reported by Marlow, is a first indication of the unreliability of his vision. The "gaps are both visual and textual: for example Jim's vision of the dark abyss before he jumps into the sea is mirrored by typographical blanks in the text, such as aposiopesis, unfinished sentences and fragmented dialogues" (Delmas 15). The narrative points at the indecisiveness of the story, so that the whole picture is blurred. What Ian Watt has defined as "delayed 
decoding", a narrative device aimed at underlining "the semantic gap between the sensations aroused in the individual by an object or event, and their actual cause or meaning" (Watt 270), rather tends here to deconstruct and annihilate the vision.

Catherine Delmas's words about the deconstruction of Orientalism in Conrad fittingly apply to what the protagonist undergoes in the ship: Jim's eyes "are arrested by the discovery of an unexpected detail which resists interpretation, and corresponds to the intrusion of the Real into the space of the picture. Vision is then reversed, as the painting or the page, instead of being offered to the viewer's or reader's tranquil gaze (Barthes's studium), suddenly captures the reader's attention: instead of looking at the page or the painting, the reader or viewer is suddenly looked at (the punctum), from the fold or the gap in the painting/text [...]" (Delmas 15). This reversal happens when Jim notices a parched passenger "whose eyes entreated him together with the voice" (Conrad 1989, 109). Gradually his romanticized vision becomes hazy and fragmented, the picture cracks up. He stops seeing, as he is being seen by the others around him, becoming the object they look at in the process.

On board the Patna, Jim stands petrified and becomes unable to see clearly, contrary to what he pretends. The words "still", "motionless", "silent" spread in the text and contaminate the character: "the power of the written word" (Conrad 1990, xlii) dictates Jim's fate in the same way as the evocation of the name of the d'Urbervilles condemns Tess from the very first page of Hardy's novel. Jim is literally turned into an object: "The sights it showed him had turned him into cold stone from the soles of his feet to the nape of his neck" (Conrad 1989,114), making him as still and solid as the "tough old iron" of the ship (115), a fact Jim himself acknowledges: "I flinched no more than a stone. I was as solid standing there as this,' he tapped lightly with his knuckles the wall beside his chair" (110).

The "strange noise" (Conrad 1989, 106) that is supposed to signal the inevitable "annihilation" (114) awaiting the ship, has a similarly petrifying effect and functions like an auditory punctum. Jim seems dehumanized and depersonalized - reified. He loses consciousness of what is going on: about what would make him move again on board the Patna, "he knew no more than the uprooted tree knows of the wind that laid it low" (123).

13 What is on the verge of annihilation, after all, is not the ship but reason itself. Every member of the crew shows signs of madness: Jim witnesses the "new antics" (Conrad $1989,118)$ of the "four men fighting like mad" (121), while "there was an element of burlesque in his ordeal" (120). He is deprived of any chance of becoming a hero and is faced with the nonsensicality of the situation. The absurdity of it all only grows and grows, until the resolution of the case with the reappearance of the ship ashore and all the passengers safe.

14 Amid such nonsense, Jim's capacity to see and hear is impaired. He becomes trapped in a process in which his identity disintegrates and he finds himself immobile and silent, just like the Patna, just like an object, a thing, unable to act and decide, subjected to a dim and meaningless perception of the scene:

Twice, he told me, he shut his eyes in the certitude that the end was upon him already, and twice he had to open them again. Each time he noticed the darkening of the great stillness. The shadow of the silent cloud had fallen upon the ship from the zenith, and seemed to have extinguished Every sound from her teeming life. He could no longer hear the voices under the awnings. He told me that each time he closed his eyes a flash of thought showed him that crowd of bodies, laid out for 
death, as plain as daylight. When he opened them, it was to see the dim struggle of four men fighting like mad with a stubborn boat. [...] His eyes fell again. "See and hear... See and hear," he repeated twice, at long intervals, filled by vacant staring. ${ }^{5}$

(Conrad 1989, 120-121) which Conrad would rather call the most "fatuous" (Conrad 1912, 306) of all -: the Titanic. Her tragic destiny brought him to write an article entitled "Some Reflections on the Loss of the Titanic - 1912" which was first published in The English Review ${ }^{6}$ in May 1912. 

ironic tone is equally present. Hardy suggests the inhuman and extravagant dimension of the tragedy by not mentioning human losses and by attributing the cause to "The Immanent Will that stirs and urges everything" (Hardy 2001, 307). He provides no description of the event and he does not refer to the people who died on that day, but carefully depicts the material effects of the "convergence" of the iceberg and the ship:

The Convergence of the Twain

(Lines on the loss of the "Titanic")

I

In a solitude of the sea

Deep from human vanity,

And the Pride of Life that planned her, stilly couches she.

\section{II}

Steel chambers, late the pyres

of her salamandrine fires,

Cold currents thrid, and turn to rhythmic tidal lyres.

III

Over the mirrors meant

To glass the opulent

The sea-worm crawls - grotesque, slimed, dumb, indifferent.

IV

Jewels in joy designed

To ravish the sensuous mind

Lie lightless, all their sparkles bleared and black and blind.

$\mathrm{V}$

FATHOM, 6 | 2019 
Dim moon-eyed fishes near

Gaze at the gilded gear

And query: 'What does this vaingloriousness down here?' ...

VI

Well: while was fashioning

This creature of cleaving wing,

The Immanent Will that stirs and urges everything

VII

Prepared a sinister mate

For her - so gaily great -

A Shape of Ice, for the time far and dissociate.

VIII

And as the smart ship grew

In stature, grace, and hue,

In shadowy silent distance grew the Iceberg too.

IX

Alien they seemed to be:

No mortal eye could see

The intimate welding of their later history,

$\mathrm{X}$

Or sign that they were bent

By paths coincident

On being anon twin halves of one august event,

XI

Till the Spinner of the Years

Said 'Now!' And each one hears,

And consummation comes, and jars two hemispheres.

(Hardy 2001, 306-307)

hubris, when Conrad's condemnation is direct. The latter's sarcasm in the article is foiled by Hardy's sadly ironical images in the poem: "the pyres" have become "rhythmic tidal lyres" (Hardy 2001, 306). "Over the mirrors [...] [t]he sea-worm crawls" (306); "the smart ship" (307) now lies "[i]n a solitude of the sea" (306). The contrast between former brilliancy and wealth on board the ship and the current darkness that surrounds her in the poem expresses Hardy's own vision of "human vanity" (306) as the true cause of the catastrophe. Although the Immanent Will could appear to clear man of any responsibility, the allusion to this external, mechanical force combined with images of decay in the poem results in a heightened sense of human tragedy and of loss, to echo the word commonly used in relation to the event and chosen by Conrad and Hardy too. Whereas most poems by Hardy leave an overall impression of nostalgia and sustained longing for the lost object, "The Convergence of the Twain" is tainted by elegy: the loss is irrecoverable and definitive. The object is forever unreachable in this realm of death.

\section{Knitting machines}

The two authors undeniably share the same ironic vision of the event and are led to the same sort of interrogation about human existence. Although the literary forms they choose and the ultimate answers they give may be different, the feelings and the questioning raise similar issues. 
dy's answer is largely linked to his conception of the Immanent Will which he first mentioned in his extensive narrative poem inspired by the Napoleonic wars and initially published between 1904 and 1908: The Dynasts. In the Fore Scene of the epic poem, one character of the tragic chorus says:

[...] like a knitter drowsed,

Whose fingers play in skilled unmindfulness,

The Will has woven with an absent heed

Since life first was; and ever will so weave. (Hardy 1965, 2) metaphor or philosophical concept. The image of the automatic spinning - of a spinning machine - recalls Conrad's knitting machine, which he depicted in a letter to his friend R.B. Cunningham Graham on December $20^{\text {th }}, 1897$ :

There is - let us say - a machine. It evolved itself (I am severely scientific) out of a chaos of scraps of iron and behold! - it knits. I am horrified at the horrible work and stand appalled. I feel it ought to embroider - but it goes on knitting. You come and say: 'This is all right; it's only a question of the right kind of oil. Let us use this for instance - celestial oil and the machine will embroider a most beautiful design in purple and gold.' Will it? Alas, no! You cannot by any special lubrication make embroidery with a knitting machine. And the most withering thought is that the infamous thing has made itself: made itself without thought, without conscience, without foresight, without eyes, without heart. It is a tragic accident - and it has happened...

It knits us in and it knits us out. It has knitted space, time, pain, death, corruption, despair and all the illusions - and nothing matters. (Watts 57)

This quotation is both an evocation of the determinist undertones in Conrad's writing and a reminder of his nihilism. This insensitive machine is depicted as the cause of human suffering: it is the only explanation Conrad can find to such tragedies as that of 
the Titanic, and this sombre outlook on the universe cannot but remind one of Hardy's own sombre vision of life.

In his radical vision of the absence of order behind the creation of the universe, Conrad creates characters who need to cling to objects - ships, a silver ring in Lord Jim, a sovereign in "Karain" - or to the salutary value of work. This is especially true for Marlow. Although he knows the horror is looming, symbolised by the darkness that envelops his journey up the Congo River, he does not follow Kurtz in his fall. He keeps himself busy with a work that appals him, but that also saves him from the devouring terror of emptiness: "I had not much time to give him, because I was helping the engine-driver to take to pieces the leaky cylinders, to straighten a bent connecting-rod, and in other such matters. I lived in an infernal mess of rust, filings, nuts, bolts, spanners, hammers, ratchet-drills - things I abominate, because I don't get on with them" (Conrad 1996, 239).

The saving power of objects and work derives from the opportunity they give one to feel alive and real, as Marlow admits: “No, I don't like work. I had rather laze about and think of all the fine things that can be done. I don't like work - no man does - but I like what is in the work, - the chance to find yourself. Your own reality - for yourself, not for others - what no man can ever know. They can only see the mere show, and never can tell what it really means" (Conrad 1996, 175). Working and being active safeguard one's individuality, keeping it away and distinct from the world around, that is to say the wilderness in Heart of Darkness.

34 Conrad's set of values is deeply human and down-to-earth, since he finds no salutary hope in transcendence. In the article on the loss of the Titanic, he therefore insists that he has "neither the competence nor the wish to take a theological view of this great misfortune, sending so many souls to their last account" (Conrad 1912, 287). Conversely, Hardy chooses to underline the theological and supernatural origin of the disaster: the Immanent Will has determined the fate of the Titanic and her passengers. His vision, although quite hopeless too, is more romantic, as he hesitates between the notion of the Immanent Will and God's will.

Hardy had been a believer in his youth. "Losing faith in Christianity was like shedding a protective skin: intellectually necessary but also a melancholy process. [...] He could no longer believe, but he cherished the memory of belief [...]" (Tomalin 78). The hesitation could reveal some feeling of fear or lack of courage. After all, Hardy did denounce the perversity of marriage in his novels,$^{10}$ and he shocked readers by writing about forbidden love relations, but in real life he never divorced his wife in spite of being estranged from her for years.

Yet it could also point out a feeling of nostalgia for his lost faith. As Timothy Hands underlines, "[j]ust as it is always important to consider how much Hardy had ever actually acquired faith, it is also important to question how fully he ever lost it" (Hands, 210). Timothy Hands goes on to argue that indecision was constitutive of Hardy's "[r]eligious [b]eliefs, [e]thical [a]ttitudes" (210) and artistic creation: "Hardy's commitment to provisionality of viewpoint, to an aesthetic dependent on freedom of the artist to deliver impressions, not argument, was impressively steadfast, consistent in its defence of the right to inconsistency" (212). Mark Asquith stresses a similar point in his article about Hardy's approach to philosophy: "Hardy's philosophical 'tentativeness', then, is less a reflection of theoretical uncertainty than the product of an aesthetic perspective which makes a virtue of perplexity" (Asquith 182). So, contrary 
to the character of Jude who clearly sees God as a malignant Other and says so at the end of the novel, ${ }_{11}^{11}$ Hardy seemed reluctant to abandon his hope for a benevolent God. To a certain extent, "replacing" God by the image of a senseless machine ${ }^{12}$ allowed Hardy to seem less defiant, but also not to have to decide between the existence, or the death, of God.

The hesitation is embodied by another character in Jude the Obscure. Indeed Sue, the protagonist's beloved, had hoped the world could be seen as a work of art: a poem, or a piece of embroidery, to echo Conrad's choice of words in his letter to R.B. Cunningham Graham. The tragic deaths of her children will bring her to endorse a bleaker vision of life:

Vague and quaint imaginings had haunted Sue in the days when her intellect scintillated like a star, that the world resembled a stanza or melody composed in a dream; it was wonderfully excellent to the half-aroused intelligence, but hopelessly absurd at the full waking; that the First Cause worked automatically like a somnambulist, and not reflectively like a sage; that at the framing of the terrestrial conditions there seemed never to have been contemplated such a development of emotional perceptiveness among the creatures subject to those conditions as that reached by thinking and educated humanity. But affliction makes opposing forces loom anthropomorphous; and those ideas were now exchanged for a sense of Jude and herself fleeing from a persecutor." (Hardy 1996, 409)

Sue abandons her idealistic interpretation to cling to a belief in an authoritarian and cruel God, a devouring Other at the origin of their tragedy. Her spiritual journey is the reverse of Jude's - and of Hardy's too: she evolves from a dreamy belief in "the First Cause" - another potential expression for the Immanent Will - to religiosity. In both respects she seems to be deluded; for the Cause did not give birth to a poem but to human suffering in an insensitive universe. Religion is accused of similar insensibility, as when Jude overhears two clergymen discussing the question of the position of the priest in the Communion Service, while Sue and he are grieving the deaths of their children: "Good God - the eastward position, and all creation groaning!" (Hardy 1998, 403).

The unclear notion of a mechanical cause that Sue comes to doubt will mature and become more defined in Hardy's writings, as he will abandon fiction after the publication of The Well Belloved in 1897 and devote himself to poetry. Step by step, as it appears in the huge poetic drama The Dynasts (1904-1908) and later in the poem "The Convergence of the Twain" (1912), the idea of a machine as "the First Cause" gets more precise.

40 I would argue that Conrad's knitting machine helps understand what Hardy had in mind with "The Spinner of the Years". What is paradoxical in both cases, however, is that this huge and malign object, this horrible machine, does not account for man's own blindness and vanity, be it exemplified in the tragedy of the Titanic or in the discussion between the two clergymen.

\section{The Fate of Modernity}

41 Tragedy is being questioned as it is relocated in the context of modernity. Fate is not in the mighty hands of God or the gods of Ancient Greece, but it is the result of the uncontrollable working of machinery. Marlow, the narrator of Heart of Darkness and Lord Jim expresses man's predicament in a famous sentence: "we live, as we dream - 
alone" (Conrad 1996, 172). Man has no more grasp on his own existence than he has on his dreams, for the machine decides on everything, and no help is to be found either on earth or in heaven. Man is subjected to the power of the machine, just as Jim is petrified on board the Patna. Objects and machines take the lead over men, their desires and the whole world, turning them into objects too.

In return, using and mastering objects is part of the virtue Marlow finds in work. If this appears to be but a second-best solution for him, the ambivalence is equally noticeable in Hardy's fiction. Jude's trade as a stonemason is seen in a positive way, partly perhaps because Hardy was himself an architect, in love with old churches and gothic constructions. Yet when it comes to modern types of works and objects, the vision is not so flattering. In Jude the Obscure, Hardy's last novel, landscapes gradually seem to be surrounded by the railways and the characters keep travelling to and fro by train rather than on foot.

If allusions to trains are rare in Tess of the d'Urbervilles, the episode of the threshing machine is a striking example of the intrusion of progress in the countryside. What could be seen as an improvement in the field of agriculture in the age of industrialisation, comes to represent danger for the human beings around. As Tess is working on the farm at Flintcomb-Ash on a bleak March morning, she appears to be subjected to the machine she serves rather than uses, and her workload is not lessened but increased by this new mode of threshing: "[...] the red tyrant that the women had come to serve - a timber-framed construction, with straps and wheels appertaining the threshing machine, [...] whilst it was going, kept up a despotic demand upon the endurance of their muscles and nerves" (Hardy 1998, 315).

The machine turns the workers into machines themselves. They become mute and dehumanized automatons, silent objects merely answering a purpose of augmented productivity: "[...] the perspiring ones at the machine, including Tess, could not lighten their duties by the exchange of many words. [...] for Tess there was no respite; for, as the drum never stopped, the man who fed it could not stop, and she, who had to supply the man with untied sheaves, could not stop either [...]" (Hardy 1998, 316-317).

The tragedy that threatens Tess as a woman - i.e. her womanhood - in her relationship to Alec, the tyrant lover, is mirrored and amplified by the tragedy that endangers her very humanity through the working of the machine. We could say that these threats eventually conquer her as she is reduced to a sign, an object at the end of the novel: "a black flag" (Hardy 1998, 384) on the horizon. Her death is enacted both in the unfolding of the diegesis and in the words on the page. ${ }^{13}$

Tess is "a pure woman" presented as a victim. However she comes to seal her own fate by killing Alec and turning herself in at Stonehenge without ever attempting to flee. Her move is coherent with Hardy's vision: he did suggest that not only the Immanent Will but man himself was responsible for man's sad destiny. In his autobiography he wrote: "Tragedy may be created by an opposing environment either of things inherent in the universe, or of human institutions. If the former be the means exhibited and deplored, the writer is regarded as impious; if the latter, as subversive and dangerous; when all the while he may never have questioned the necessity or urged the nonnecessity of either [...]" (Hardy 1962, 274).

"Human institutions" are not the result of chance but of human choices and calculations. They underline man's responsibility in the history of humanity, in men's 
lives and in the evolution of the world. Human institutions, man-made machines, people's beliefs and choices suggest that men are both subjects and objects, the doers and the victims of their own tragedies. Such irreconcilable positions form Hardy's frame of mind and writing, accounting for the complexity of his art and the opposing views of readers confronted to his work.

Conrad is not exempt from similar ambivalence. In spite of his refusal to cling to a theological understanding of the universe, he expressed man's predicament in religious words that echo his description of the loss of the Titanic as an "Act of God". Questioning the idea of immortality he wrote in an essay entitled "The Life Beyond": "Since the Day of Creation two veiled figures, Doubt and Melancholy, are pacing endlessly in the Sunshine of the world. What humanity needs is not the promise of scientific immortality, but compassionate pity in this life and infinite mercy on the Day of Judgment" (Conrad 1921, 93-94).

Hardy and Conrad are great authors and will continue to be read because they explore the heart of man, the savageness of human thoughts and feelings, the obscurity of existence. Their art is their unique weapon to resist the threat of dehumanization which they perceive in the advance of progress and in man's faith in man. Such belief is not, in their eyes, to be replaced by belief in God; but hope can be found in man's creativity and art. Hardy believed that "[ $\mathrm{t}] \mathrm{o}$ find beauty in ugliness is the province of the poet" (Hardy 1962, 213). It is the desire to make "the world resembl[e] a stanza or melody composed in a dream" (Hardy 1996, 409) - the desire to "embroider" while the machine merely "knits" - that led him to become one of the greatest writers and poets of the late Victorian period and of the Edwardian era. Similarly, Conrad's ambition was that of the writer whose task "is, by the power of the written word to make you hear, to make you feel - it is, before all, to make you see!" (Conrad 1990, xlii). For both authors, as their works show, (only) art and imagination had the strength to elevate the spirit of the time and turn objects of doom into objects of art.

\section{BIBLIOGRAPHY}

Abrams, Meyer Howard, A Glossary of Literary Terms (1957), Fort Worth: Harcourt Brace College P, 1999.

Asquith, Mark, "Philosophy, Metaphysics and Music in Hardy's Cosmic Vision”, The Ashgate Research Companion to Thomas Hardy, ed. Rosemary Morgan, Farnham: Ashgate, 2010, 181-197.

Bergmann, Meredith, “'The Convergence of the Twain': Thomas Hardy and Popular Sentiment”, Contemporary Poetry Review [Online], Thomas Hardy Special Issue (October 2012), <http:// www.cprw.com/the-convergence-of-the-twain-thomas-hardy-and-popular-sentiment> (last accessed 2 Jan 2019).

Conrad, Joseph, Preface to The Nigger of The "Narcissus" (1897), Oxford: OUP, 1990, xxxix-xliv. Conrad, Joseph, Heart of Darkness and Other Tales (1899), Oxford: OUP, 1996. 
Conrad, Joseph, Lord Jim (1900), Harmondsworth: Penguin, 1989.

Conrad, Joseph, Notes on Life and Letters, London and Toronto: Dent, 1921.

Delmas, Catherine, "Introduction: Deconstructing Orientalism in Joseph Conrad's Malay Novels", L'Époque Conradienne: Tropes and the Tropics, eds. Catherine Delmas \& Christine Vandamme, Limoges: PULIM, 2010, 11-18.

Hands, Timothy, "One Church, Several Faiths, No Lord: Thomas Hardy, Art and Belief", The Ashgate Research Companion to Thomas Hardy, ed. Rosemary Morgan, Farnham: Ashgate, 2010, 199-216.

Hardy, Florence Emily, The Life of Thomas Hardy, 1840-1928, London: Macmillan, 1962.

Hardy, Thomas, Tess of the d'Urbervilles (1891), Oxford: OUP, 1998.

Hardy, Thomas, Jude the Obscure (1895), Harmondsworth: Penguin, 1996.

Hardy, Thomas, The Dynasts: An Epic-Drama of the War with Napoleon, In Three Parts, Nineteen Acts, and One Hundred and Thirty Scenes, London: Macmillan, 1965.

Hardy, Thomas, The Complete Poems, ed. James Gibson, Basingstoke: Palgrave, 2001.

Ousby, Ian, “The Convergence of the Twain: Hardy's Alteration of Plato's Parable”, The Modern Language Review 7.4 (1982): 780-796.

Tomalin, Claire, Thomas Hardy, The Time-Torn Man, London: Penguin, 2007.

Vandamme, Christine, Lord Jim, Joseph Conrad, Paris : Bréal, 2003.

Watt, Ian, Conrad in the Nineteenth Century, Berkeley, Los Angeles: U of California P, 1979.

Watts, Cedric (ed.), Joseph Conrad's Letters to R. B. Cunninghame Graham, Cambridge: Cambridge UP, 1969.

Watts, Cedric, "Conrad, Joseph", Oxford Dictionary of National Biography [Online], <https://doi.org/ 10.1093/ref:odnb/32533> (last accessed 3 Aug 2018).

\section{NOTES}

1. Conrad stopped being a sailor and turned to writing for a living "as steam superseded sail and as vessels became larger and more efficient" (Watts, ODNB).

2. "Object, n.", OED [Online], OUP, <www.oed.com/view/Entry/129613> (last accessed 21 Oct 2018).

3. Jim is influenced by "light holiday literature" (Conrad 1989, 47) and has dreams of heroism. He is often witnessed losing contact with reality: "I could see in his glance darted into the night all his inner being carried on, projected headlong into the fanciful realm of reckless heroic aspirations. [...] With every instant he was penetrating deeper into the impossible world of romantic achievements" (104).

4. The truth is presented as "checked" and "writhing" (Conrad 1989, 101) or "obscure" (112), but never plain or "barren" (102) in the novel.

5. We may underline the fact that Jim recovers his status as a subject through the act of telling his own story. This could be his true debt to Marlow who allows him to become a narrator in his turn at some points in the narrative.

6. The English Review was launched by Conrad's friend and collaborator Ford Madox Ford. The first issue published in December 1908 included Thomas Hardy's poem "A Sunday Morning Tragedy". The link between Hardy and Conrad, therefore, might be stronger than it commonly appears. 
7. The date "April 24, 1912" can be read at the end of the manuscript (Hardy 2001, 961, n248).

8. For more details, see Bergmann.

9. When Conrad does mention a potentially metaphysical interpretation of the disaster, irony looms again as the religious allusion is immediately linked to a notion of merchant shipping. Moreover the allusion is clearly presented as hypothetical: "And if ever a loss at sea fell under the definition, in the terms of a bill of lading, of Act of God, this one does, in its magnitude, suddenness and severity; and in the chastening influence it should have on the self confidence of mankind" (Conrad 1912, 287, my emphasis).

10. In 1912, i.e. 17 years after the initial publication of Jude the Obscure, Hardy added a Postscript in which he attempted to justify the way he dealt with the theme of marriage in the novel: "My opinion at that time, if I remember rightly, was what it is now, that a marriage should be dissolvable as soon as it becomes a cruelty to either of the parties - being then essentially and morally no marriage [...]" (Hardy 1996, viii).

11. On his last encounter with Sue, Jude derides religion for being as harmful as alcohol: "I was gin-drunk; you were creed-drunk. Either form of intoxication takes away the nobler vision..." (Hardy 1996, 467). The benevolent God has disappeared and what remains is human suffering, expressed through the verses of the Book of Job Jude recites on his deathbed (484).

12. "The activities of the Immanent Will and the Spinners of the Years recall the role of God in Genesis" (Ousby 783).

13. Tess's sister appears as a "pale" (Hardy 1998, 383) copy of the heroine, as if to atone for her tragic destiny in a feeble attempt by Hardy to offer a happy ending after all. Yet what we remember of Tess in this closing chapter is the flag signalling her death, undermining the "drooping" (383) presence of the new unconvincing couple.

\section{ABSTRACTS}

Thomas Hardy and Joseph Conrad gave voice and shape to the mood of the times they lived in. They were highly aware of what changes progress brought about in people's lives in the late $19^{\text {th }}$ and early $20^{\text {th }}$ centuries. Conrad wrote lengthily about sailboats, steamships and vessels. Hardy depicted landscapes surrounded by railways and field workers using a threshing machine. Such objects of modern civilization led them to question the value of progress and to warn readers about the dangers of dehumanization. In their writings, man's predicament appears to be heightened rather than alleviated by the quest for advancement, leading both Hardy and Conrad to give a new form to tragedy in their fiction.

Thomas Hardy et Joseph Conrad ont su parler de leur époque. Tous deux sont les témoins des changements sociétaux induits par les progrès de la fin du $19^{\text {ème }}$ et du début du $20^{\text {ème }}$ siècles. Les écrits de Conrad sont remplis de bateaux à voiles, à vapeur, et de navires. Ceux de Hardy dépeignent des paysages entrecoupés par les lignes de chemin de fer ou des ouvriers agricoles s'affairant à faire fonctionner une batteuse. Ces objets de la civilisation moderne les conduisirent à s'interroger sur la valeur du progrès et à alerter leurs lecteurs sur leur dangerosité potentielle. Le destin des hommes et des femmes paraît plus sombre encore face à cette course au développement, si bien que Hardy et Conrad en viennent à dessiner les contours nouveaux d'une tragédie moderne dans leur fiction. 


\section{INDEX}

Mots-clés: objets, déshumanisation, tragédie, machines, Titanic, Volonté Immanente, machine à tricoter, Conrad (Joseph)

Keywords: objects, dehumanization, tragedy, machine, Titanic, Immanent Will, knitting machine, Conrad (Joseph)

oeuvrecitee Tess of the d'Urbervilles, Jude the Obscure

\section{AUTHOR}

\section{STÉPHANIE BERNARD}

Stéphanie Bernard is Assistant Professor at the University of Rouen (France) where she is in charge of teacher training. She wrote a thesis on Thomas Hardy and Joseph Conrad, dealing with the treatment of the tragic in the early days of modernism. In addition, she has been focusing on the question of otherness in literary works (femininity, intertextuality and rewriting), widening her approach to other texts by Hardy, including his poems and short stories, and to other nineteenth and twentieth authors such as Charlotte Brontë, Jean Rhys and C.S. Lewis. She was the convenor of the conference on "Objects in Thomas Hardy and Joseph Conrad" that was held in Rouen in May 2018. 